\title{
Effects of newly developed solutions containing trehalose on twenty-hour canine lung preservation
}

Trehalose is a nonreducing disaccharide that stabilizes the cell membrane under various stressful conditions. A previous study demonstrated that trehalose was effective in 12-hour canine lung preservation. We have developed new preservation solutions containing trehalose: an extracellular type ET-Kyoto solution ( $\mathrm{Na} 100 \mathrm{mmol} / \mathrm{L}, \mathrm{K} 44 \mathrm{mmol} / \mathrm{L}$ ) and an intracellular type IT-Kyoto solution ( $\mathrm{Na}$ $20 \mathrm{mmol} / \mathrm{L}, \mathrm{K} 130 \mathrm{mmol} / \mathrm{L}$ ). The composition of these solutions is identical except for the electrolyte content. We examined their efficacy in 20-hour lung preservation. Canine lungs were flushed with ET-Kyoto (group A, $n=6$ ), with IT-Kyoto and prostaglandin $E_{1}(25 \mu \mathrm{g} / \mathrm{kg})($ group B, $n=6)$, or with Euro-Collins solution and prostaglandin $E_{1}\left(25 \mu \mathrm{g} / \mathrm{kg}\right.$ ) (group $\mathrm{C}, n=7$ ), and stored for 20 hours at $4^{\circ}$ C. Left lung transplantation was performed and evaluated for up to 130 minutes. The flush time was similar in the three groups. Arterial oxygen tensions (inspired oxygen fraction $=0.5$ ) in group $A$ were uniformly excellent $(303.3 \pm 7.0 \mathrm{~mm} \mathrm{Hg} 70$ minutes after reperfusion and $303.0 \pm 19.6 \mathrm{~mm} \mathrm{Hg} 130$ minutes after reperfusion) and significantly higher than in group B $(202.6 \pm 32.0 \mathrm{~mm} \mathrm{Hg}, p<0.05$, and $197.8 \pm 44.0 \mathrm{~mm} \mathrm{Hg}, p=0.054$, respectively $)$ or group $\mathrm{C}(185.9 \pm 23.0 \mathrm{~mm} \mathrm{Hg}, p<0.01$, and $155.7 \pm 36.3 \mathrm{~mm} \mathrm{Hg}, p<0.05$, respectively). Peak inspiratory pressure in group A was significantly lower than in groups $B$ and $C .(p<0.05)$. Wet/dry weight ratio in group $A$ was significantly lower than in groups $B(p<0.05)$ and $C(p<0.01)$. Histologic and scanning electron microscopic examinations showed better preservation in group A than in groups B and C. We conclude that ET-Kyoto is superior to IT-Kyoto and to Euro-Collins solution for 20-hour lung preservation. (J THORAC CARDiovaSC SuRG 1994;108:92-8)

Toru Bando, MD, Shinji Kosaka, MD, Chunjiang Liu, MD, Takashi Hirai, MD, Toshiki Hirata, MD, Hiroyasu Yokomise, MD, Kazuyuki Yagi, MD, Kenji Inui, MD, Shigeki Hitomi, MD, and Hiromi Wada, MD, Kyoto, Japan

\footnotetext{
A though lung transplantation has been established as a therapeutic option for patients with end-stage lung disease, a shortage of suitable donor lungs limits its widespread application. With the growing experience in bilateral sequential lung transplantation, ${ }^{1}$ ischemic times of more than 6 hours are now commonplace in clinical practice. Improved methods of lung preservation would increase the supply of transplantable lungs and reduce acute and chronic complications. In liver transplantation,

From the Department of Thoracic Surgery, Chest Disease Research Institute, Kyoto University, Kyoto, Japan.

Received for publication Oct. 25, 1993.

Accepted for publication Jan. 28, 1994.

Address for reprints: Hiromi Wada, MD, Department of Thoracic Surgery, Chest Disease Research Institute, Kyoto University, Shogoin Sakyo-ku, Kyoto 606, Japan.

Copyright $\odot 1994$ by Mosby-Year Book, Inc.

$0022-5223 / 94 \$ 3.00+0 \quad 12 / 1 / 55547$
}

University of Wisconsin solution (UW), which can provide reliable preservation for more than 24 hours, ${ }^{2}$ has been applied clinically and is widely established. Most clinical lung transplantation programs have preserved donor lungs with prostaglandin ( $\mathrm{PGE}_{1}$ or $\mathrm{PGI}_{2}$ ) pretreatment followed by pulmonary arterial flushing with EuroCollins solution (EC) ${ }^{3}$ However, a reliable clinical technique of lung preservation beyond 9 hours has not been achieved yet. In animal experiments, a number of investigators have studied extensively the effectiveness of various solutions, such as EC, UW, and low-potassium dextran, in lung preservation for more than 18 hours, ${ }^{4-6}$ but the results are not satisfactory enough to be applied directly to clinical situations.

Trehalose $\left(\mathrm{C}_{12} \mathrm{H}_{22} \mathrm{O}_{11}\right)$ is a nonreducing disaccharide (1- $\alpha$-D-glucopyranosyl-1- $\alpha$-D-glucopyranoside) with a molecular weight of 342 and consists of two D-glucose moieties connected by a 1,1-linkage. It exists in many 
Table I. Composition of preservation solutions

\begin{tabular}{lccc}
\hline & $\begin{array}{c}E T-K \\
\text { solution }\end{array}$ & $\begin{array}{c}I T-K \\
\text { solution }\end{array}$ & $\begin{array}{c}E C \\
\text { solution }\end{array}$ \\
\hline $\mathrm{Na}(\mathrm{mmol} / \mathrm{L})$ & 100 & 20 & 10 \\
$\mathrm{~K}(\mathrm{mmol} / \mathrm{L})$ & 44 & 130 & 115 \\
$\mathrm{Cl}(\mathrm{mmol} / \mathrm{L})$ & - & - & 15 \\
Gluconate $(\mathrm{mmol} / \mathrm{L})$ & 100 & 106 & - \\
Phosphate $(\mathrm{mmol} / \mathrm{L})$ & 25 & 25 & 58 \\
Bicarbonate $(\mathrm{mmol} / \mathrm{L})$ & - & - & 10 \\
Glucose $(\mathrm{gm} / \mathrm{L})$ & - & - & 35 \\
Trehalose $(\mathrm{gm} / \mathrm{L})$ & 41 & 41 & - \\
Hydroxyethyl starch $(\mathrm{gm} / \mathrm{L})$ & 30 & 30 & - \\
Osmolarity (mOsm/L) & 366 & 370 & 355 \\
\hline
\end{tabular}

prokaryotes, fungi, yeasts, some desert plants, and insect body fluid. ${ }^{7}$ In the human body, trehalose yields glucose on hydrolysis by trehalase. Trehalose has been shown to stabilize or protect cell membrane structures under various environmental stresses, such as desiccation, freezing, and high temperatures. ${ }^{7-11}$ The effectiveness of trehalose in canine lung preservation has been examined in our laboratory with the use of a modified EC solution in which $3.5 \%$ or $7 \%$ trehalose replaces glucose. The composition of the solutions is identical except for the saccharide (glucose or trehalose). $\mathrm{We}^{12}$ have shown that EC containing trehalose provides significantly better preservation than standard EC (containing glucose) for 12-hour cold storage. Although EC containing trehalose shows good results in 12-hour lung preservation, reliable 20-hour preservation has not been achieved (unpublished data). Several components other than trehalose are needed to improve lung preservation. We have developed two new types of preservation solution that contain $4.1 \%$ trehalose, hydroxyethyl starch, and gluconate (Table I). ET-Kyoto solution (ET-K) is an extracellular type of solution with high sodium and low potassium content $(\mathrm{Na}$ $100, \mathrm{~K} 44 \mathrm{mmol} / \mathrm{L}$ ), and IT-Kyoto solution (IT-K) is an intracellular-type solution ( $\mathrm{Na} 20, \mathrm{~K} 130 \mathrm{mmol} / \mathrm{L})$. In the present study, the efficacy of ET-K and IT-K for 20-hour lung preservation was examined in canine lung allotransplantation.

\section{Materials and methods}

Animals. Pairs of size-matched adult mongrel dogs weighing 8.3 to $14.4 \mathrm{~kg}$ were assigned randomly to three groups. In group A $(n=6)$ lungs were flushed with ET-K, in group B $(n=6)$ with IT-K, and in group $\mathrm{C}(n=7)$ with $\mathrm{EC}$, and they were stored at $4^{\circ} \mathrm{C}$ in their respective solutions. In groups $\mathrm{B}$ and $\mathrm{C}$, $\mathrm{PGE}_{1}$ pretreatment was used before the flushing. The composition of the solutions is shown in Table I. ET-K and IT-K solutions were generously provided by Roussel Morishita Co. Ltd., Osaka, Japan, and EC solution was supplied by the Green Cross Corporation, Osaka, Japan.

Anesthesia. Induction and maintenance of anesthesia were
Table II. Donor data

\begin{tabular}{lccc}
\hline & Group A & Group B & Group C \\
\hline CIT (min) & $1193.0 \pm 4.5$ & $1199.0 \pm 4.0$ & $1197.7 \pm 12.0$ \\
WIT (min) & $65.3 \pm 5.5$ & $65.0 \pm 2.0$ & $59.7 \pm 6.5$ \\
Flush time (sec) & $72.5 \pm 6.9$ & $83.7 \pm 4.0$ & $65.7 \pm 3.8$ \\
$\mathrm{PaO}_{2}(\mathrm{~mm} \mathrm{Hg}) *$ & $311.8 \pm 21.8$ & $286.9 \pm 7.5$ & $313.3 \pm 7.7$ \\
$\mathrm{PaCO}_{2}(\mathrm{~mm} \mathrm{Hg}) *$ & $23.9 \pm 3.0$ & $23.2 \pm 1.1$ & $26.1 \pm 1.0$ \\
PIP (cm H $\left.\mathrm{H}_{2} \mathrm{O}\right){ }^{\dagger}$ & $17.2 \pm 0.5$ & $17.7 \pm 0.5$ & $16.4 \pm 0.8$ \\
PVR & $402.0 \pm 112.4$ & $435.5 \pm 71.2$ & $273.1 \pm 39.0$ \\
$\quad$ & & &
\end{tabular}

All values are mean \pm standard error of the mean. $C I T$, Cold ischemic time; $W I T$, warm ischemic time; $\mathrm{PaO}_{2}$, arterial oxygen tension; $\mathrm{PaCO}_{2}$, arterial carbon dioxide tension; $P I P$, peak inspiratory pressure; $P V R$, pulmonary vascular resistance. *Arterial oxygen and carbon dioxide tensions during bilateral ventilation with an inspired oxygen fraction of 0.5 .

†Peak inspiratory pressure of the recipient before the operation.

performed as described previously. ${ }^{12-14}$ The dogs' lungs were ventilated with an inspired oxygen fraction of 0.5 at a tidal volume of $20 \mathrm{ml} / \mathrm{kg}$, a respiration rate of 15 breaths $/ \mathrm{min}$, and a positive end-expiratory pressure of $5 \mathrm{~cm} \mathrm{H}_{2} \mathrm{O}$. Anesthetic gas of nitrous oxide was used with $0.5 \%$ to $2.0 \%$ halothane during the operation.

Donor procedure. A right femoral venous catheter (SwanGanz catheter; Baxter Healthcare Corp., Edwards Div., Irvine, Calif.) and an arterial catheter were introduced. Arterial blood gas analysis, peak inspiratory pressure, and systemic and pulmonary hemodynamics were recorded. Pulmonary vascular resistance (PVR) was calculated as follows: PVR $=$ $([\mathrm{PAP}-\mathrm{PCWP}] / \mathrm{CO}) \times 80 \mathrm{dyne} \cdot \mathrm{sec} \cdot \mathrm{cm}^{-5}(\mathrm{PAP}$, mean pulmonary arterial pressure; PCWP, pulmonary capillary wedge pressure; $\mathrm{CO}$, cardiac output). After median sternotomy, the azygos vein was divided and the superior and inferior venae cavae, aorta, and pulmonary artery were encircled. After a heparin injection $(200 \mathrm{units} / \mathrm{kg})$, the main pulmonary artery was cannulated with a $5 \mathrm{~mm}$ aortic arch cannula through a 3-0 Prolene pursestring suture (Ethicon, Inc., Somerville, N.J.). In groups $B$ and $C$, a large bolus of $\mathrm{PGE}_{1}(25 \mu \mathrm{g} / \mathrm{kg})$ was injected into the right ventricular outflow. When the systemic pressure declined by at least $40 \%$, the superior and inferior venae cavae and aorta were divided and the proximal pulmonary artery was ligated. The left atrial appendage was amputated, and the lungs were inflated to a maximum inspiratory pressure until all atelectasis was eliminated. The pulmonary artery was flushed by gravity from a height of $50 \mathrm{~cm}$ with cold $\left(4^{\circ} \mathrm{C}\right)$ perfusate 70 $\mathrm{ml} / \mathrm{kg}$ (ET-K, IT-K, or EC). Ventilation of the lungs was continued during the pulmonary artery flush and the duration of flushing was recorded. The defect in the cannula insertion site of the pulmonary artery was closed after removal of the cannula, and the left atrial appendage was ligated. Under the endotracheal pressure of $20 \mathrm{~cm} \mathrm{H}_{2} \mathrm{O}$, the trachea was clamped and the heart-lung block was excised with minimal handling of both lungs. The block was then placed in a sterile plastic bag containing $1000 \mathrm{ml}$ of the cold corresponding solution and stored at $4^{\circ} \mathrm{C}$ for 20 hours. After the 20-hour storage, the right lateral basal segment $\left(\mathrm{S}^{9}\right)$ of the donor lung was excised for scanning electron microscopic examination.

Recipient procedure. Recipients were anesthetized, and Swan-Ganz and arterial catheters were introduced as in the donor procedure. Blood gases, peak inspiratory pressures, and 


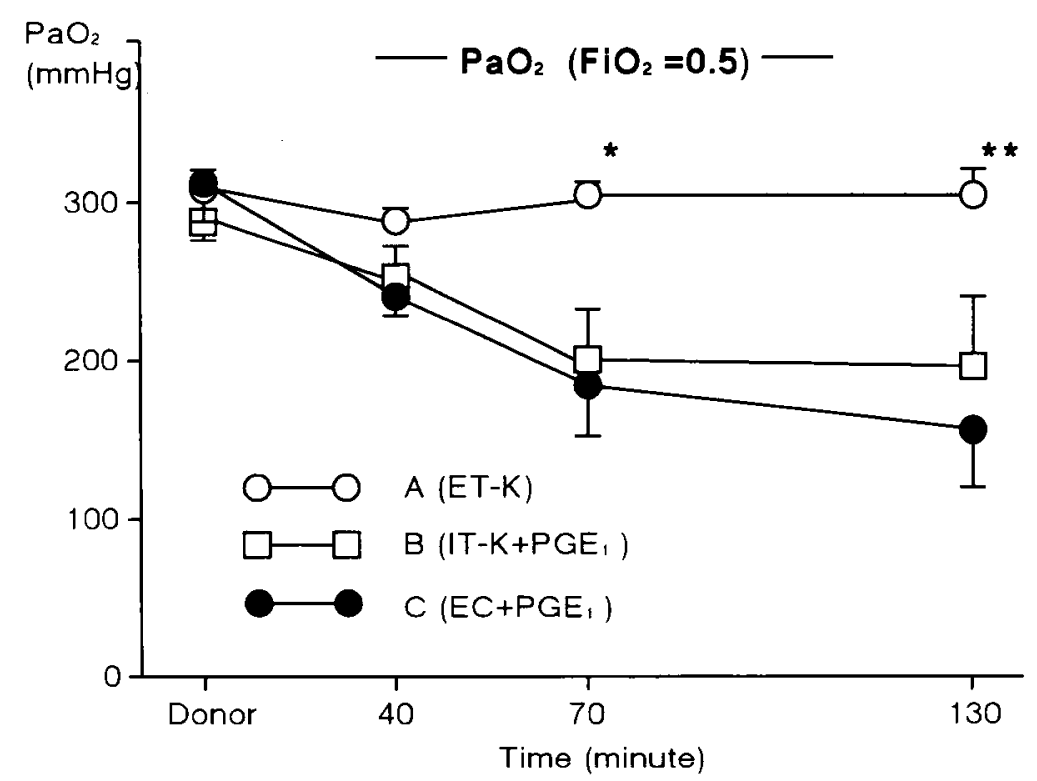

Fig. 1. Arterial oxygen tension $\left(\mathrm{PaO}_{2}\right)$ of donor and transplanted lungs (mean \pm standard error). * $p<0.01$, ET-K versus EC; $p<0.05$, ET-K versus IT-K. ${ }^{* *} p<0.05$, ET-K versus EC. Fio 2 , Inspired oxygen fraction.

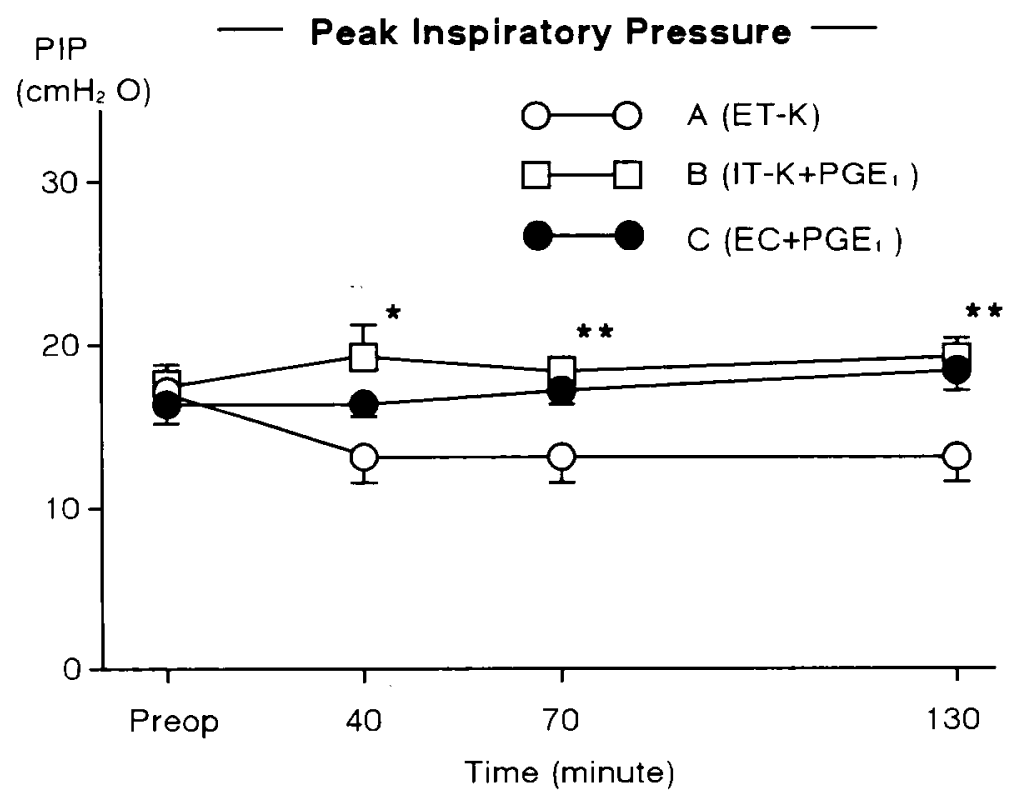

Fig. 2. Peak inspiratory pressure $(P I P)$ of transplanted lungs (mean \pm standard error). ${ }^{*} p<0.05$, ET-K versus IT-K; ${ }^{* *} p<0.05$, ET-K versus IT-K and EC. Preop, Before operation on recipients.

systemic and pulmonary hemodynamics were recorded. After pneumonectomy, single left lung transplantation was performed as described previously. ${ }^{12-14}$ Anastomosis was performed in the order of the left atrium, the left main bronchus, and the pulmonary artery. The left pulmonary artery was anastomosed during ventilation of both lungs. At 40,70 , and 130 minutes after reperfusion, the right pulmonary artery was clamped for $5 \mathrm{~min}$ - utes and blood gas analysis, peak inspiratory pressure, pulmonary artery pressure, systemic blood pressure, and heart rate were recorded. Pulmonary capillary wedge pressure and cardiac output were measured 130 minutes after reperfusion. After the final assessment the dogs were killed. The apical posterior $\left(S^{1+2}\right)$ and lateral basal $\left(S^{9}\right)$ segments of the transplanted lung were excised and examined histologically. The apical posterior 
$\left(\mathrm{S}^{\mathrm{I}+2}\right)$ and anterior medial basal $\left(\mathrm{S}^{8}\right)$ segments of the transplanted lung were excised and dried at $70^{\circ} \mathrm{C}$ for 72 hours, and the wet/dry weight ratio was calculated.

Statistical analysis of the data was performed by analysis of variance, Scheffe's multiple comparison test, and paired, twotailed $t$ test. A $p$ value less than 0.05 was considered significant. All data are expressed as mean \pm standard error of the mean.

All animals received humane care in compliance with the "Principles of Laboratory Animal Care" formulated by the National Society for Medical Research and the "Guide for the Care and Use of Laboratory Animals" prepared by the National Academy of Sciences and published by the National Institutes of Health (NIH Publication No. 86-23, revised 1985).

\section{Results}

Donor data. Cold and warm ischemic times were similar in the three groups. The flush time was also similar in all groups and the quality of flush was equivalent in all groups according to subjective criteria such as rapid blanching and absence of mottling. No significant differences were detected among the three groups with regard to arterial oxygen and carbon dioxide tensions, peak inspiratory pressure, and pulmonary vascular resistance of the donor lungs before harvest (Table II).

Recipient data. All animals but one could survive the final assessment. One animal in group $\mathrm{C}$ died after the assessment at 70 minutes after reperfusion.

Arterial blood gas analysis. In group A, the arterial oxygen tension of the transplanted lung with 5 minutes' occlusion of the right pulmonary artery 40,70 , and 130 minutes after reperfusion were uniformly excellent $(289.4 \pm 5.7,303.3 \pm 7.0$, and $303.0 \pm 19.6 \mathrm{~mm} \mathrm{Hg}$, respectively), and they were significantly higher than in groups $\mathrm{B}$ and $\mathrm{C}$ after 70 minutes' reperfusion $(p<0.05$ versus group $\mathrm{B}, 202.6 \pm 32.0 \mathrm{~mm} \mathrm{Hg} ; p<0.01$ versus group $\mathrm{C}, 185.9 \pm 23.0 \mathrm{~mm} \mathrm{Hg}$ ) and higher than in group $C$ after 130 minutes' reperfusion ( $p=0.054$ versus group B, $197.8 \pm 44.0 \mathrm{~mm} \mathrm{Hg} ; p<0.05$ versus group $\mathrm{C}$, $155.7 \pm 36.3 \mathrm{~mm} \mathrm{Hg}$ ) (Fig. 1). In group A, the arterial carbon dioxide tension of the transplanted lung 40,70 , and 130 minutes after reperfusion were $26.6 \pm 2.5$, $25.5 \pm 2.3$, and $25.1 \pm 1.9 \mathrm{~mm} \mathrm{Hg}$, respectively; in group B they were $28.9 \pm 4.6,30.5 \pm 5.8$, and $30.3 \pm 5.7 \mathrm{~mm} \mathrm{Hg}$; and in group C, $27.5 \pm 3.3$, $25.6 \pm 2.0$, and $28.6 \pm 2.5 \mathrm{~mm} \mathrm{Hg}$, respectively. No significant difference in arterial carbon dioxide tension after reperfusion was detected among the three groups.

Peak inspiratory pressure. In group $\mathrm{C}$, the peak inspiratory pressure increased significantly with the duration of reperfusion ( $p<0.05,40$ minutes versus 130 minutes), whereas in groups A and B, the pressures were almost constant after reperfusion. The peak inspiratory pressure in group A was significantly lower than in group

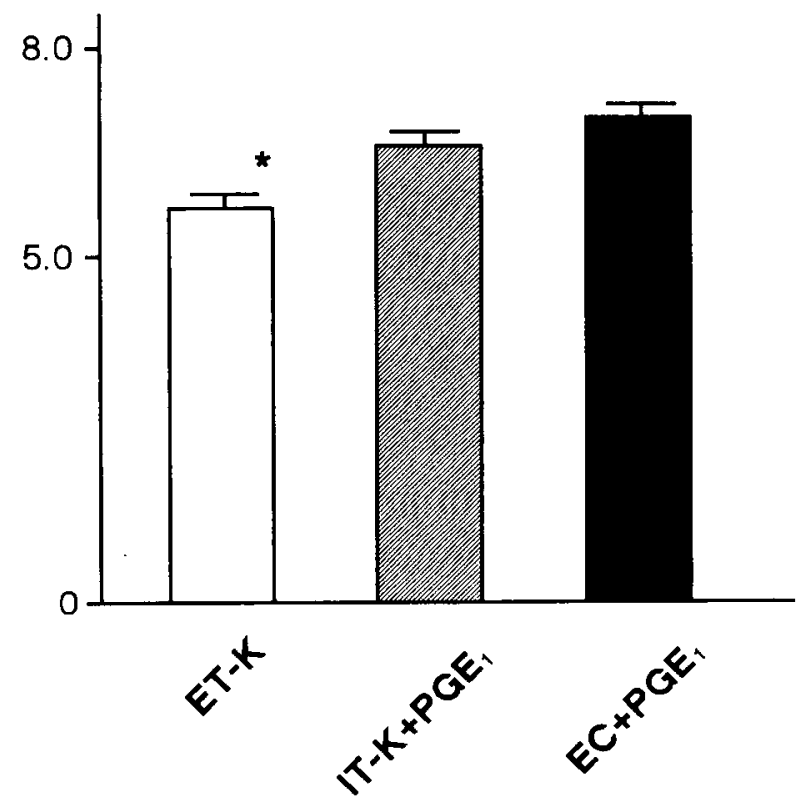

Fig. 3. Wet/dry weight ratio of transplanted lungs (mean \pm standard error). ${ }^{*} p<0.01$, ET-K versus EC; $p<0.05$, ET-K versus IT-K.

$B$ after 40 minutes' reperfusion (group A, $13.0 \pm 1.3 \mathrm{~cm}$ $\mathrm{H}_{2} \mathrm{O}$; group $\left.\mathrm{B}, 19.2 \pm 2.0 \mathrm{~cm} \mathrm{H}_{2} \mathrm{O} ; p<0.05\right)$ and lower than in groups $\mathrm{B}$ and $\mathrm{C}$ after 70 minutes' reperfusion (group A, $13.0 \pm 1.4 \mathrm{~cm} \mathrm{H}_{2} \mathrm{O}$; group B, $18.3 \pm 0.9 \mathrm{~cm}$ $\mathrm{H}_{2} \mathrm{O}$; group $\left.\mathrm{C}, 17.2 \pm 0.9 \mathrm{~cm} \mathrm{H}_{2} \mathrm{O} ; p<0.05\right)$ and after 130 minutes' reperfusion (group A, $13.1 \pm 1.2 \mathrm{~cm} \mathrm{H}_{2} \mathrm{O}$; group $\mathrm{B}, 19.1 \pm 1.4 \mathrm{~cm} \mathrm{H}_{2} \mathrm{O}$; group $\mathrm{C}, 18.5 \pm 1.4 \mathrm{~cm}$ $\mathrm{H}_{2} \mathrm{O} ; p<0.05$ ) (Fig. 2).

Pulmonary vascular resistance. In group $A$, the pulmonary vascular resistance of the transplanted lung 130 minutes after reperfusion was $1022.6 \pm 209.3$ dyne $\cdot \mathrm{sec} \cdot \mathrm{cm}^{-5}$. The corresponding values were $1476.1 \pm 174.0$ in group B and $1296.5 \pm 213.4$ in group C. No significant difference was detected among the three groups.

Wet/dry weight ratio. The wet/dry weight ratio of the transplanted lung was $5.72 \pm 0.21$ in group $\mathrm{A}$, significantly lower than in group B $(6.52 \pm 0.17$, $p<0.05)$ and in group $\mathrm{C}(7.00 \pm 0.26, p<0.01)$ (Fig. $3)$.

Histologic examination. Histologic studies demonstrated almost normal structures and no sign of pulmonary edema in group $A$. Two of six animals in group $B$ and one of the seven in group $C$ showed no histologic evidence of edema; the remaining four dogs in group $\mathrm{B}$ and six in group $\mathrm{C}$ showed thickening of the alveolar septum (mild pulmonary edema).

Scanning electron microscopic examination. Scan- 

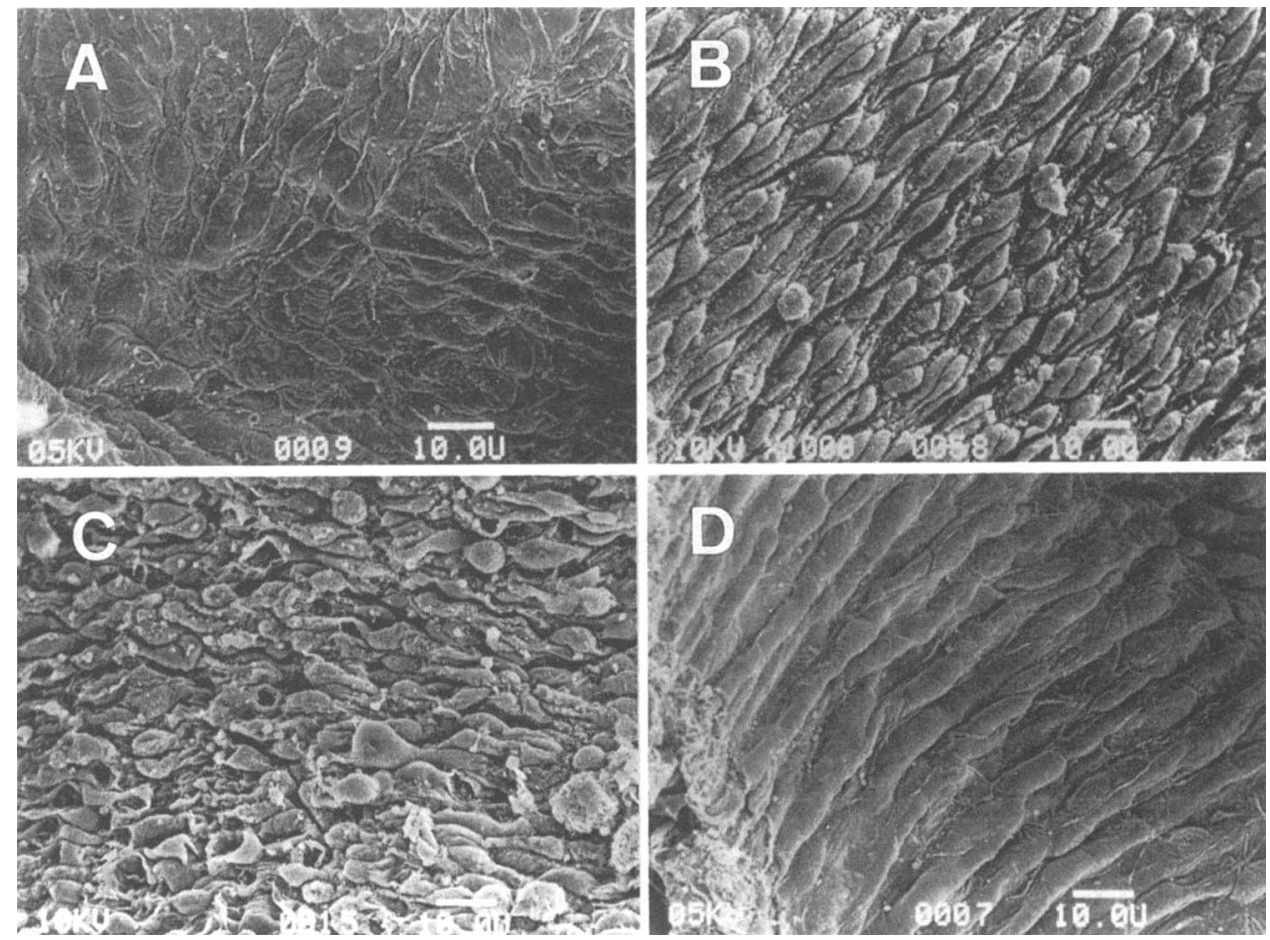

Fig. 4. Representative scanning electron microscopic findings of preserved lungs. Normal canine pulmonary arterial endothelium with intact architecture (D). Scanning electron micrograph of endothelial surface in group A (A) showed almost normal structures preserved. Significant endothelial swelling was evident in group B (B) and disruption of endothelial cell structures in group $\mathrm{C}(\mathbf{C}) .($ Lines $=10 \mu \mathrm{m}$.

ning electron microscopy revealed almost normal endothelial structures in group A after 20 hours of storage (Fig. 4, $A$ and $D$ ), whereas significant endothelial swelling was detected in group B (Fig. 4, $B$ ) and disruption in group C (Fig. 4, C).

\section{Discussion}

Among the strategies to increase the supply of transplantable lungs is the development of methods to improve lung preservation that minimize ischemic lung injury. Extending preservation time for lung grafts to more than 20 hours would permit semielective surgery in clinical lung transplantation. Clinically, the most widely used method of organ preservation is hypothermic pulmonary arterial flush with EC after pretreatment with prostaglandin. The limit of the safe ischemic time of this method is considered to be approximately 9 hours. ${ }^{3}$ Recently, Hardesty and associates ${ }^{15}$ reported that UW provided a comparable preservation with EC despite its longer ischemic time. Puskus and colleagues ${ }^{4}$ reported that in 18-hour canine lung preservation with either low-potassium dextran or EC with $\mathrm{PGE}_{1}$, no significant difference in transplanted lung function was found between the groups. Aeba and colleagues ${ }^{16}$ investigated the effectiveness of UW in 12-hour rat lung preservation without prostaglandin. No significant difference was detected between UW and EC. Oka and coworkers ${ }^{17}$ reported that low-potassium dextran was superior to UW and EC for 30-hour rabbit lung preservation with $\mathrm{PGE}_{1}$ and that no significant difference in efficacy existed between UW and EC. Recently, Kawahara and colleagues ${ }^{5}$ reported that UW with $\mathrm{PGE}_{1}$ provided better survival than $\mathrm{EC}$ with $\mathrm{PGE}_{1}$ in 24-hour canine lung preservation. The results of experimental lung preservation with UW are controversial, and it is still unclear whether $U W$ is definitely superior to EC.

We investigated the effectiveness of two new types of solution, ET-K and IT-K, which contain $4.1 \%$ trehalose, hydroxyethyl starch, and gluconate. Trehalose stabilizes or protects the cell membrane structure under various stressful conditions such as desiccation, freezing, and high temperatures. ${ }^{7-11}$ Crowe and associates ${ }^{8}$ reported that trehalose binds to the polar head of membrane phospholipid and prevents fusion and gelatinization of the cell membrane during dehydration. $\mathrm{We}^{12}$ described previous- 
ly the effect of trehalose on 12-hour lung preservation. During cold storage, lung injury seems to be caused by ischemia and hypothermia, which can destroy the cell membrane structure and its function. Scanning electron microscopy showed that damage to endothelium in groups $\mathrm{A}$ and $\mathrm{B}$ was less than to that in group $\mathrm{C}$. Trehalose may produce a stable environment around the endothelial cell membrane and act as a thermoprotectant against lung injury.

It is still unclear whether a high-potassium concentration solution for the lung is beneficial. In experimental lung preservation, Yamazaki and colleagues ${ }^{18}$ reported that an extracellular solution (low-potassium dextran) was superior to an intracellular solution (EC) for 18 -hour preservation. However, most clinical organ transplant programs have used an intracellular solution containing a high-potassium concentration (EC or UW) for organ preservation. Intracellular solutions have been considered to induce pulmonary vasoconstriction during flushing, causing interruption of homogeneous flushout. ${ }^{3}$ Therefore, a vasodilator $\left(\mathrm{PGE}_{1}\right.$ or $\mathrm{PGI}_{2}$ ) is currently used during organ procurement to prevent vasoconstriction caused by a high-potassium solution. In the present study, an extracellular solution (ET-K), even without $P G E_{1}$, provided significantly better preservation than intracellular solutions (IT-K and EC) with $\mathrm{PGE}_{1}$. The oxygen tension of transplanted lungs in group $\mathrm{A}$ was uniformly excellent and significantly higher than that in groups $\mathrm{B}$ and $\mathrm{C}$, although the difference between groups $\mathrm{A}$ and $\mathrm{B}$ did not reach statistical significance at 130 minutes after reperfusion $(p=0.054)$. The impairment of lung function after preservation with intracellular solutions may be due not only to damage during flushing but also to injury during hypothermic storage.

ET-K and IT-K also contain gluconate and hydroxyethyl starch. Gluconate was used as an anion in the place of chloride. Chloride ion passes freely through the cell membrane to draw water into the cell, but the cell membrane is much less permeable to gluconate, which has a greater molecular weight (MW 196) than chloride (MW 35.5). ${ }^{19}$ This limited passage may help to reduce cell swelling under hypothermic conditions. Hydroxyethyl starch is believed to create osmotic pressure, to prevent interstitial edema, and to facilitate vascular flushout of organs for preservation. ${ }^{20}$

We have demonstrated that ET-K provides reliable 20-hour lung preservation in dogs, even without $\mathrm{PGE}_{1}$. Our comparison of ET-K and IT-K suggests that a low-potassium solution has a more beneficial effect on lung preservation. Further studies are needed to examine the efficacy of ET-K for longer periods of preservation, to evaluate the importance of the various components, and to compare ET-K with UW. It is expected that ET-K may be of clinical use and may help in achieving the goal of elective lung transplantation.

\section{REFER EN CES}

1. Kaiser LR, Pasque MK, Trulock EP, Loe DE, Dresler CM, Cooper JD. Bilateral sequential lung transplantation: the procedure of choice for double-lung replacement. Ann Thorac Surg 1991;52:438-46.

2. Jamieson NV, Sundberg R, Lindell S, et al. Preservation of the canine liver for 24-48 hours using simple cold storage with UW solution. Transplantation 1988;46:51722.

3. Cooper JD. Current status of lung transplantation. Transplant Proc 1991;23:2107-14.

4. Puskas JD, Cardoso PFG, Mayer E, Shi S, Slutsky AS, Patterson GA. Equivalent eighteen-hour lung preservation with low-potassium dextran or Euro-Collins solution after prostaglandin $\mathrm{E}_{1}$ infusion. J THORAC CARdiovasc SuRG 1992;104:83-9.

5. Kawahara K, Itoyanagi $\mathrm{N}$, Takahashi $\mathrm{T}$, Akamine $\mathrm{S}$, Kobayashi M, Tomita M. Transplantation of canine lung allografts preserved in UW solution for 24 hours. Transplantation 1993;55:15-8.

6. Date H, Matsumura A, Manchester JK, et al. Evaluation of lung metabolism during successful 24-hour canine lung preservation. J THORAC CARDIOVASC SURG 1993; 105:48091.

7. Wiemken A. Trehalose in yeast, stress protectant rather than reserve carbohydrate. Antonie Van Leeuwenhoek 1990;58:209-17.

8. Crowe LM, Crowe JH, Rudolph A, Wormersley C, Appel L.Preservation of freeze-dried liposomes by trehalose. Arch Biochem Biophys 1985;242:240-7.

9. Virgilio CD, Simmen U, Hottiger T, Wiemken A. Heat shock induces enzymes of trehalose metabolism, trehalose accumulation, and thermotolerance in Schizosaccharomyces pombe, even in the presence of cycloheximide. FEBS Lett 1990;273:107-10.

10. Crowe JH, Crowe LM. Preservation of membranes in anhydrobiotic organism: the role of trehalose. Science 1984;223:701-3.

11. Emyanitoff RG, Wright BE. Effect of intracellular carbohydrates on heat resistance of Dictyostelium discoideum spores. J Bacteriol 1979;140:1008-12.

12. Hirata T, Fukuse T, Liu CJ, et al. Effects of trehalose in preservation of canine lung for transplants. Surgery [In press].

13. Hirai $T$, Wada $H$, Hasegawa $S$, et al. The immunosuppressive effect of FK 506 on canine lung transplantation. $\mathrm{J}$ Thorac Cardiovasc Surg 1992;103:1127-35.

14. Hasegawa S, Wada H, Yokomise H, et al. Combination use 
of suboptimal dose of FK 506 and cyclosporine in canine lung transplantation. J Thorac Cardiovasc Surg 1992;104:1340-8.

15. Hardesty RL, Aeba R, Armitage JM, Kormos RL, Griffith BP. A clinical trial of UW solution for pulmonary preservation. J THORAC CARDIOVASC SURG 1993; 105:6606.

16. Aeba R, Keenan RJ, Hardesty RL, Yousem SA, Hamamoto I, Griffith BP. University of Wisconsin solution for pulmonary preservation in a rat transplant model. Ann Thorac Surg 1992;53:240-6.

17. Oka T, Puskus JD, Mayer E, et al. Low-potassium UW solution for lung preservation. Transplantation 1991; 52:984-8.

18. Yamazaki F, Yokomise H, Keshavjee SH, et al. The superiority of an extracellular fluid solution over Euro-Collins' solution for pulmonary preservation. Transplantation 1990;49:690-4.

19. Belzer FO, Southard JH. Organ preservation and transplantation. Prog Clin Biol Res 1986;224:291-303.

20. Belzer FO, Southard JH. Principles of solid-organ preservation by cold storage. Transplantation 1988;45: 673-6. 